\begin{tabular}{|r|c|c||}
\hline Received: November 2017 & Accepted: January 2018 & Published: April 2018 \\
\hline \hline Article DOI: http://dx.doi.org/10.24903/sj.v3i1.154 \\
\hline
\end{tabular}

\title{
Second Language Writing Instruction: A recent practice in Indonesia
}

\author{
Elsa Widya Hapsari \\ Lembaga Pengelola Dana Pendidikan (LPDP) \\ Chulalongkorn University \\ elsawidya1989@gmail.com \\ Pornpimol Sukavatee, Ph.D \\ Chulalongkorn University \\ jipornpimol@gmail.com
}

\begin{abstract}
Today, a majority of people appear to agree that with the rapid development of English, writing skills cannot be isolated as a standout amongst the most critical skills (Ali \& Hasanah, 2014; Asrifan, 2015). Mustafa and Samad (2015, p. 32) identified two roles of writing for English learners. To start with, it promotes the learners' thinking skills, manages the ideas, and enhances their ability in concluding, analyzing and criticizing. Also, it encourages learning, thinking and reflecting on their ability in English. Besides, Brown (2007) emphasizes that writing is an ability that cannot be produced naturally. Writing is often viewed as a result of the thinking, drafting and revising process that requires particular skills.
\end{abstract}

Keywords: Second language writing, narrative writing, digital story writing, writing instruction, technology in writing, visual in writing.

\section{INTRODUCTION}

Second language writing has been gaining importance in recent years (Hyland, 2003; Matsuda, 2003; Musa, 2016). Many researchers have found some facts that show second language (L2) writing is different from first language (L1) writing. Mostly, students suffer when writing in the second language because second language writing involves more complex thinking skills. (Silva, 1993, p. 669) stated that "L2 writing is strategically, 
rhetorically and linguistically unique in important ways from L1 writing." Hyland (2003) identified some differences that distinguish L2 and L1 writing in the following aspects:

i) linguistic proficiencies and institutions about language

ii) learning encounters and classroom expectations

iii) sense of audience and writer

iv) preferences for ways of organizing texts

v) writing processes

vi) comprehension of texts used and the social value of different text types

In recent years, several countries in Asia face similar problems in English as second language writing. (Kumpawan, 2014) conducted her thesis related to writing and reported that the ability of students in Thailand did not meet the standards of the Ordinary National Education Test (ONET) in 2011. She claimed that it was an indication that the English proficiency of Thai students needed to be improved. She found that average English scores were the lowest compared to other subject areas. The result showed that of the four skills in English, writing was deemed by Thai students to be the most difficult skill to learn. Even though ONET does not have writing component as part of the test, the researcher suggested that it is one of the factors which hinder students in learning English, due to its complex structure, vocabulary, grammar, and rhetorical order. It led to an investigation of the reason behind the weak ONET scores. Kumpawan revealed that Thai students lack practice in learning writing and yet they are required to accomplish complex tasks such as report and essay writing, especially at upper secondary level.

In Malaysia, research conducted by Zakaria, Yunus, Nazri, and Shah (2016) about writing in English as a second language (ESL) narrative texts, reported that students whose background was urban and upper class did not have problems in writing because they usually speak and write in English on a daily basis. This was different from those who come from the rural areas, where English is not used as frequently. Therefore, writing has a high tendency to become a problem for most of these students.

Apart from speaking (a required skill that must be mastered by graduates in order to seek positions in a company), writing is seen as another compulsory skill that cannot be neglected in Malaysia. Government and private sectors mostly charge the job seekers to take a preliminary writing test before they are allowed to go to the interview session. Regarding 
this issue, another rising problem which appeared from students' perception is the motivation to write. Malaysian students claim that they tend to get bored easily with the conventional approach. Moreover, the teachers are expected to give more attention to writing instruction, which provides a particular aid, support, and assistance in order to enhance students' writing skills.

Some difficulties in second or foreign language writing problems are also reported by Webb (2015). She investigated the English writing for a global context: an examination of a native speaker (NS) English as a Second Language (ESL), and English as a Foreign Language (EFL) learning strategies that work in Thailand. She stated that students who are exposed to English in their daily lives might learn the communication skills quickly. However, for students who only learn English as a subject in the classroom, the aspects of language such as lexicon, syntax as well as structure and grammar are major concern in terms of developing their writing skill. Consequently, teachers and students should spend a lot of time checking the content and correcting the errors in grammar.

In Indonesia, a study conducted by Sukandi (2015) entitled Teaching Writing to Indonesian EFL students: Challenges of the "voice" and "style" in Adjusting Cross-Cultural Communication Skills found linguistic conditions of Indonesian EFL students which are similar to Webb's. Students in Indonesia generally face similar problems in writing, such as grammatical weakness, poor vocabulary and, more specifically, a weak ability to express their thoughts clearly. Indeed, students should be able to acquire more knowledge and experience to overcome these problems, such as by having more motivation, initiative and curiosity about the writing practice.

It is even more complicated due to the interference of the first language (L1) writing in Indonesia. For example, the past tense used in English does not exist in Bahasa Indonesia (the first language). Indonesian students often add an adverb of time at the end of the sentence to show the past events, while in English, the action verbs are changed by putting a new form of the verbs. Obviously, where tenses are a completely new thing for students, they might feel frustrated when learning them (Ariyanti, 2016; Megaiab, 2014).

Today, learning English writing in Indonesia is considered as a second language. Writing in Bahasa Indonesia is a crucial skill that all students in Indonesia must acquire because it is the official language of Indonesia. It is used as a medium of communication 
among Indonesian people. The reason for this is the variety of tribes from all the islands in Indonesia. There are more than three hundred local languages spoken by different ethnic groups as their first language or mother tongue.

Sukandi (2015) mentioned that where English is used as a second language, students receive a huge input of English in their daily lives. Meanwhile, in Indonesia, it is not common to use English as a language of instruction, even at schools. Teachers in general use Bahasa Indonesia or their first language to deliver lessons, except for international schools. The consequence is that Indonesian students might feel learning English writing is difficult because of the absence of some grammatical features in Bahasa Indonesia.

\section{METHODOLOGY}

The purpose of this paper is to review English writing skills, writing instruction, EFL narrative writing, and the technology, motivation and use of visual aids in writing instruction. The review includes theories and findings of previous studies in Indonesia and other countries as follows.

\section{Elements of Writing Skills}

In order to become a satisfactory English writer, a few elements embedded in writing skill have to be considered including composition, vocabulary, grammar, and mechanics (Lipson \& Wixson, 2003). Accordingly, the first element is composition, which is defined as a process that guides a learner to produce a piece of writing. It usually includes prewriting, drafting, revising, editing, and publishing. The second element is vocabulary development. In fact, vocabulary is an important part of writing as without it writer will not be able to express an idea. Also, vocabulary is the representative of a writer's prior knowledge. With prior knowledge, a writer is able to convey messages or share thoughts with the audience. Consequently, the lack of knowledge about one particular topic will lead a writer to confusion when composing texts.

The other three elements are grammar, usage and mechanics. Grammar is defined as a set of rules that arrange words into a meaningful unit, whereas usage refers to the language used by the writer to attract readers, for example, occasions, audiences, and goals. Hence, different targets or readers might affect different language standards used by the writer. The last one is the mechanics. It includes punctuation and capitalization. They are crucial in writing because both of them will determine meaning. When speaking or listening, people are 
able to pause or stop the conversation, or use an appropriate tone. In writing, people are not be able to do so. Therefore, the mechanics perform the same task in writing.

Other aspects stated by Canale and Swain (1980) such as grammatical competence, discourse competence, sociolinguistic competence and strategic competence are taken into consideration. As a result, both teachers and students realize that is not easy to be a good writer, especially where English is taught as a second or foreign language.

In conclusion, a good writing skill consists of several elements including composition, vocabulary, grammar, and mechanics. As learners are expected to acquire all of these elements, writing is considered to be one of the most difficult skills. Widiati and Cahyono (2006) stated that writing is considered as one of the most sophisticated skills among the other three skills, i.e. speaking, listening and reading. Pan (2008) mentioned that even in the first language, writing is still considered as a difficult skill to learn due to certain aspects of composition, such as stating the main idea, selecting vocabulary, and grammar. Consequently, people need to utilise specific strategies to learn writing skills. Therefore, it will be more complicated when students have to learn how to write in other languages.

\section{Writing Instruction}

According to Johnson-Sheehan (2005) instruction is a set of steps that must be followed to achieve a goal. There are several characteristics of good instruction, for example, introductions, a list of the conditions, graphics, information, and conclusions. Jefferson (as cited in Abdel-Hack \& Helwa, 2014) defines instruction as 'a freestanding document that supports other documents' consisting of elements such as graphics and reference, while Horner, Nordquist, and Ryan (2017) identify instruction as a direction to perform specific procedures or steps in order to accomplish a task. Based on these definitions, writing instruction can be defined as a procedure or steps which consist of some information and other supporting documents to achieve the goal in teaching writing.

Brown and Lee (2015) suggested some principles in teaching writing skills, which aim to integrate the practice of how to be good writers. They stated that to provide help for students to become good writers, there are some guidelines that teachers can follow, such as:

- selecting and assigning the writing task carefully

- paying attention to the main idea 
- quantifying the audience

- time planning

- trying to write the first ideas onto the paper

- following the structure when writing

- not being rigid to the specific structures

- revising the work with willingness

- allowing efficient time for making the necessary revisions.

Next, they suggest striking a balance between process and product. Since writing is not an instant process of learning, teachers need to make sure that students are taught by using corresponding stages.

A third principle takes into consideration the students' cultural or literary backgrounds. Students may need assistance in writing because not all of them know the English rhetorical conventions.

Fourthly, connections between reading and writing need to be made. It is obvious that by exposing students to a variety of written texts, they will be able to write about a particular topic or subject matter. These texts should also be as authentic as possible. Students need to see real writing inside and outside the classroom in order to be able to write.

\section{Writing Instruction in Indonesia}

According to the current Indonesian national curriculum (Education, 2016), teaching writing in Indonesia focuses on the text genre, such as narratives, descriptions, recounts, expositions and argumentative texts. Sukandi (2015) identified two main factors that teachers should bear in mind when teaching writing which focuses on genre, related to pedagogy and social issues. This is because students in Indonesia come from different parts of the island. They have their own regional mother tongue as their first language. This is a challenge that all the teachers face in Indonesia (Sukandi, 2015). Thus, in this situation, appropriate strategies and approaches are significant in writing instruction.

Many researchers conducted research in Indonesia to find out about writing conditions. What they discovered is very revealing. Megaiab (2014) undertook a study investigating Indonesian senior high schools students' writing competence. The study found that the first language might affect students' ability to learn English. The distinct form and 
formula that does not appear in the mother tongue inhibits students learning English as a foreign language. Therefore, it is inevitable that students will make mistakes, especially in language features such as grammar (e.g. spelling, preposition, tenses, etc.).

Research in Banda Aceh Indonesia conducted by Mustafa, Kirana, and Bahri Ys (2016) entitled Errors in EFL writing by Junior High Students in Indonesia reported similar problems faced by junior high school levels. The main problem that Indonesian students need to cope with is the grammatical errors, such as word form, articles, non-finite verbs, tenses, and prepositions. Another study conducted by Ferdhiyanto (2014) about the problem in the written production of Indonesian students also found similar problems. It revealed that common grammar problems faced by junior high school students' writing included the use of tenses, plurality, and prepositions.

Another issue which arose from the distinction between L1 and English is the mechanics, such as punctuation and capitalization. Therefore, the teachers should spend sufficient time in teaching writing regardless of its difficulties. The teachers are expected to be able to overcome these problems by implementing an effective method of instruction, both inside and outside the classroom, because writing is an act of practicing (Ariyanti, 2016). Perhaps enough time to practice and good writing instruction will enhance their writing skills.

Research conducted in MAN Bangil by Megawati and Anugerahwati (2012) on Java Island in Indonesia included a study on the teaching of writing narrative texts to Indonesian EFL students. The research type was classroom action research. A preliminary study conducted by the researchers showed that most of the students were not good enough in writing narrative texts. It was found that most of the students could not achieve the minimum criterion of the passing grade, which was $70 \%$.

The reasons for this made apparent during the observation process. Students seemed demotivated and struggled to start their writing. The factors influential during the writing process were that English was not an interesting lesson for them, there was less variety of teaching strategies employed by the teachers, an inappropriate amount of new vocabulary, difficult grammar aspects and a lack of media used in the classroom (Megawati \& Anugerahwati, 2012).

Sakkir, Rahman, and Salija (2016) studied about students' perception of social media in writing classes. They stated that one of the reasons why writing is important is because it 
helps Indonesian learners to get better jobs. Sharing the same belief with the Malaysian government, more companies in Indonesia require applicants to have good writing skills. Moreover, applicants will be able to handle responsibilities which mostly focus on writing activities, such as writing letters, e-mails, and reports. However, Indonesian students' writing ability is still unsatisfactory. They have difficulties in many writing aspects, such as spelling, punctuation, structure, ideas, and organization.

For this reason, writing instruction in Indonesia has to be equipped with an effective methodology so that the learners will have more time to practice how to be a good writer. Writing is essential; hence students need to focus on the process of rewriting, revising, and editing (Wang, 2012). Perhaps by having enough allotment of time, students will be able to improve their writing skills.

Unlike the other three skills (speaking, listening and reading) writing requires more time to be practiced by students due to its complex problems and difficulties. However, in Indonesia, most teachers use "the traditional one-off writing task". It is defined as a writing instruction which allocates a single meeting only for writing skills (Ariyanti, 2016). In addition, the teacher's role seems very dominant and uses a lot of teacher-talking time. Thus, it lessens the effectiveness of teaching instruction, especially in writing, where those who have to practice are the students, not the teachers. The teachers often assign the students to write a text and award a grade for it. Bearing in mind that writing is an activity which requires several phases, Gibbons (2002) emphasized many processes in writing which include topic selection, outlining, drafting, revising, editing and proofreading. As a consequence, with a short period of time to learn writing, it is an extremely challenging thing for students to be a good writer. In this case, the teachers should provide assistance for them in terms of giving more time to practice, plus supervision and feedback both inside and outside the classroom (Ariyanti, 2016; Mustafa et al., 2016).

In Indonesia, the importance of the Information and Communication Technologies (ICTs) is also stated in the Minister of Education and Culture Regulation Number 21/2013 (Education, 2016). Teachers are encouraged to integrate the use of ICT in the teaching and learning process. Fortunasari (2016) in her previous research reported that ICTs were significant in providing a solution to teaching issues, improving the literacy level in the context of EFL and helping the government to reform the curriculum in terms of the practice of ICT in the educational field. 
Despite the advantages of ICTs use in the educational context, several challenges were reported in the implementation. Firstly, the government programs of ICTs are only available in the big cities, especially in the capital or provinces in Indonesia, while in the isolated areas the programs are not fully conducted or do not work effectively. Hence, it affects the teachers' competence in integrating the ICTs into teaching. Moreover, some teachers do not realize the positive effects of the use of ICT itself. In sum, the programs should be provided for the teachers so they will be able to use technology in their teaching.

\section{English Curriculum 2013}

According to the Minister of Education and Culture Regulation Number 21/2016, Junior and Senior High School Graduates aim to obtain balanced attitudes/values, knowledge, and skills (Education, 2016). As the matter of fact, every school's subjects are expected to develop attitude, knowledge, and skills relevant to the nature of the subject (Priyana, 2014). In the competence section of the curriculum, it is stated that students must be able to develop and edit short written and spoken texts that are orderly and chronologically structured and linguistically accurate. Specifically, on the basic competence section, it is written that the goal of English learning is to develop the students' ability to communicate with accuracy and appropriateness in the target language in the four language skills and in a variety of contexts for varied purposes, using a range of text types and language functions (Priyana, 2014, p. 2).

\section{Writing Skill of Eighth- grade students}

Values: Gratitude, enthusiasm, honesty, discipline, responsibility, care, politeness, confidence, cooperation, and peace.

Text types:

1. Short and simple descriptive texts about humans, animals, and things

2. Short and simple recount texts about activities, events and phenomena

3. Short and simple narrative texts about fables

\section{Short functional texts:}

1. Personal invitation letters

2. Greeting cards

3. Short messages

4. Announcement/notices

5. Songs 
According to the recommendations from The Ministry of Education and Culture, there are a number of learning principles that should be applied for all subjects, including English. Below are some of the principles:

1. Students are facilitated to learn

2. The learning process applies the scientific approach

3. Learning is competency-based

4. Students learn from varied learning sources

\section{Technology-Supported Writing}

Today, adolescents are exposed to the use of technology. "Millennial students who are known as "Digital Natives" demand a rather different approach of teaching and learning as they have been surrounded by digital tools in their lives, resulting in the change of their thinking patterns" Prensky (as cited in Zakaria et al., 2016, p.210). It is undeniable that students today rely highly on technology. Over many years, technology has been a part of L2 classrooms and teachers are expected to be able to integrate it into their teaching, including writing instruction (Brown \& Lee, 2015; Harmer, s.d; Hyland, 2003).

Technology offers a solution to help both teachers and students in order to compete in the educational field. Quite recently, considerable attention has been paid to teaching instruction which involves technology because it is believed to be one tool to help teachers in assisting students to have a role in $21^{\text {st }}$ century literacies. McAdams (2013) conducted a study on Innovate Literacy Instruction with a Classroom Computer: A Solid Rationale for the Integration of Special Digital Tools in America. He demonstrated the feasibility of the impact of technology in the digital age on education. Moreover, much support is enabled through the help of educational professionals, including the Society for Technology in Education (ISTE) and The National Writing Project (NWP). While ISTE focused on promoting a forum for educational stakeholders so they would be able to effectively make use of technology in teaching and learning, the NWP launched a Technology Initiative (TI) in 2004, whose goal was to increase the quality of writing program within schools with the assistance of technology. Another concern is to provide a source for teachers to expand their network, together with other teachers, by opening the access of the local sites which enable them to stay in touch with professional development. 


\section{EFL Narrative Writing}

In Indonesia, English writing is taught using the genre approach, which focuses on four different texts; descriptions, narratives, recounts and argumentative texts. Genre orientation aims to focus on the connection between discourse and contextual aspects of language, such as grammar and linguistic patterns. It is not merely a tool for writers to write for a particular reader, but also as a means of communication. This is consistent with the definition of writing, which is a means of communication among people.

Narrative writing is essential for students. Knapp and Watkins (1994) support this by stating that the narrative is a popular genre among students. They believe that it is the most appropriate approach to teach writing because people are generally more exposed to narratives than other genres. Unfortunately, the popularity of the narrative does not necessarily make it easy to be understood. Smith (2011), emphasized that narrative writing learning is essential because it consists of multidimensional processes, which includes components, word-level skills (e.g. spelling), language skills (e.g. grammar and syntactic awareness), vocabulary, and mechanics.

In addition, most of the studies of narrative writing in Indonesia were conducted in the context of higher education. In Indonesia, in the national curriculum for eight grades, writing instruction gives more attention on teaching descriptive and recount texts. It is stated that students will learn descriptive texts about humans, animals, and things, along with simple recount texts about activities, events, and phenomena. Meanwhile, narrative texts are only delivered through fables or fairytales (Education, 2016).

According to Boucher (as cited in Abdul-Hack et al., 2002) narrative writing is a story that comes from an individual experience. It is typically created from the first person point of view that covers feeling, sensory details, and elements to attract the readers. It encourages the writer to share their stories about themselves and experiences. Narrative writing aims to tell the audience about an event that can come from both reality and imagination. It has a particular format of time, dependent on the story. The writers have many purposes for creating narrative writing, such as giving information, instructing, persuading or providing entertainment.

In English learning, students do the narrative writing intentionally to create fictional stories, memoirs, anecdotes, and autobiographies. Later on, they will be able to add details 
such as scenes, objects, people, and actions. Dialogue is another feature that students can develop in narrative writing. They can insert the characters, personalities, and motives to their stories.

\section{Digital Narrative Writing}

Several publications have appeared in recent years documenting the importance of digital writing, particularly in teaching narrative texts, such as the use of multimedia. There are many studies which show the usefulness of using multimedia in the learning process. Martin (2012) suggests in an English Literature study that the cognitive load was eased by the use of multimedia, and the greatest development was found where multimedia was integrated with animation, audio, explanation, and background.

Kent (2015) emphasizes many advantages of using multimedia to teach narrative writing. The latest study conducted in Malaysia about using a multimedia named Storybird demonstrated positive impacts on students' narrative writing. Zakaria et al. (2016) emphasized that teachers should promote the use of Storybird into the classroom because of its advantage in helping students to write a narrative. The layout is beautiful and attractive, so the learners are engaged in the process of learning.

In Indonesia, a study conducted by Cahyono and Mutiaraningrum (2015) about the use of narrative learning multimedia (NLM) in the form of a movie, pictures, and texts resulted in better ways in teaching the narrative text. The use of NLM attracted students' attention in the narrative text through the involvement of schematic structures and linguistic features. Therefore, the combination of visual and digital aids is highly recommended when teaching narrative writing.

\section{Digital Story Writing}

A digital story is a media which consist of scripts, and first person narratives. It is also a mixture of conventional and modern storytelling where people are able to use video, music, and narration (Robin (2006). Another definition comes from Hull and Nelson (2005) who stated that digital story is a type of multimedia which consists of images and segments of video with background music and a voice-over narrative. According to Lambert (as cited in Wen 2017), a digital story consists of three elements; the beginning, middle, and end. 
Moreover, a good story is a story that attracts the audience's attention at the beginning and the resolution at the end, sometimes with an unpredictable twist.

Several publications have appeared in recent years documenting several digital story platforms, which provide advantages for students in writing skills, such as wikis, hypermedia authoring, computer-generated graphic organizers, digital writing communities and online writing communities. Pifarré Turmo and Fisher (2011) conducted research involving students aged nine and ten with the use of wikis in their writing lessons. The study found that wikis provide help for students to be able to engage in both reading and writing tasks. It was mentioned that by integrating wikis, students use their higher order thinking skills, revising skills and other skills such as sharing, discussing, and debating. Similar to Piffare and Fisher, hypermedia authoring (a web page design that incorporates a variety of digital tools) conducted by Wen (2017) promotes students' creative thinking by focusing on one aspect of the content. They argued that students who are not familiar with the system and disconnected activities would be distracted by having more than one component together.

Another supporting literature from Abdel-Hack and Helwa (2014) also reported the advantages of integrating digital stories in writing instruction. This study was conducted in the Faculty of Education, Benha University, Egypt. The study was about digital storytelling and weblogs instruction to enhance EFL narrative writing and critical thinking skills. It was found that digital stories are an effective tool to teach narrative writing and critical thinking skills. The key features of digital stories are reading, writing, and sharing. Firstly, when the learners read stories from other authors, it will increase their exposure. Next, the visual aids were found to be attractive and meaningful. Another bonus is that students can move back and forth between the observation and learning process.

"Thus, through digital story students develop communication skills, learn to ask questions, express opinion, construct narrative and write for audience, improve also their language and computer skills by using software that combines a variety of multimedia: text, images, audio, video, and web publishing (Abdel-Hack \& Helwa, 2014, pp. 3-4)”.

Another tool which is found to be helpful for students is a graphic organizer. It works by enabling the writers to stick to the topic by organizing their ideas in a spatial form. Students' ability to integrate their known knowledge with the new was enhanced (McAdams, 2013). A study conducted using computer software such as Kidspiration, Popplet and 
Concept Board revealed that (1) graphic organizers foster students' development in organizational skills, particularly among young learners, (2) students become more excited in speaking as compared to using the traditional template graphic organizer, and (3) students have a longer attention-span on the writing session (Lorenz, Green, \& Brown, 2009).

Pifarré Turmo and Fisher (2011) came to the conclusion that to achieve the development of $21^{\text {st }}$ century skills, students should embed the use of technology in their learning. One way to implement this is through the use of digital tools. However, to make sure that it works, teachers should consider the following; first, is to build strong reasons for the use of digital tools. Next is that the selection of the tools should be based on researchbased best practices. Teachers should also be equipped with sufficient knowledge and skills regarding the best practice used in digital tools. Therefore, with coordination among the stakeholders, the practice of digital tools will succeed.

Word processing has also had an effect in terms of teaching writing. Hyland (2003) mentioned that the features in a word processor allow students to cut and paste, check the grammar, insert images and print. One of the main advantages is that it provides an opportunity for students to work collaboratively. However, Hyland claimed that just using the new tools in teaching writing is not enough. Perhaps with a good instruction, which involves appropriate tasks and support, students can master the writing skills faster.

\section{Visuals and Writing}

Many studies emphasized that visuals have numerous advantages in guiding students in how to write in ESL or EFL writing. In the article by Yunus, Salehi, Tarmizi, Syed, and Balaraman (2011), their findings in the study of using digital comics were (1) the comics were able to assist lower achievers in terms of promoting writing in English and (2) that there was an increase in students' motivation to write.

According to Levie \& Leintz; Levin, Anglin \& Corney (as cited in Jun Liu, 2014) visuals play an important role in reading through the following:

1. Representation: Visuals provide assistance in understanding the text's content

2. Organization: Visuals enhance the text coherence

3. Interpretation : Visuals provide more real information 
4. Transformation: Visuals target critical information in the text and recode it in a memorable form

5. Decoration: Visuals are used for their aesthetic properties or to spark readers' interest in the text.

Wright and Hallem (as cited in Ali \& Hasanah, 2016) also consider that pictures have a major role to play in the development of students' skills. They mention two reasons; (1) the meaning we derive from words is affected by the context they are in (pictures can represent or contribute much to the creation of contexts in the classroom) and (2) it is often helpful if the students can respond to a text non-verbally; pictures provide an opportunity for nonverbal response (2014, P. 233)

Abuzahra, Farrah, and Zalloum (2016) mention the significance of integrating visuals into writing skills. The use of visual representation has positive impacts in enhancing students' writing skills for several reasons: Firstly, it involves students participating in a classroom discussion using key words included in the word cloud. Next, it enables students to use animation like Wordle as a reflection tool for writing projects. Last., it encourages students to utilize word clouds on other writing topics, as well as encouraging students to produce ideas for new writing topics or themes.

Ramirez (2016) conducted her thesis on the usage of multimedia visual aids in the English classroom and discovered that visuals provide input for students so that the learning process is less complicated. They help teachers by lessening the use of the mother tongue and direct translation.

Ali and Hasanah (2014) emphasized many key findings of using pictures in teaching writing, listed below:

1. It is better to use a series of pictures to convey students' ideas in narrative writing rather than the conventional method

2. Visual materials are easy to apply and are attractive

3. The importance of the visual may lead to understandings that both teacher and students may use in the classroom

4. Pictures used in the classroom can be a useful tool to engage student's attention. They also create attractive situations among the students.

5. Visuals provide stimulus for student discussions regarding real life concepts. 
6. Pictures are available both outside and inside the classroom so they are a very helpful tool for the teachers.

Another finding from Asrifan (2015) is that teaching using a picture story can help students achieve higher in comparison to the conventional way of writing. Many of the studies used pictures in narrative writing due to the versatility of narrative writing. It is the most appropriate genre to teach in the classroom. Students are able to arrange their ideas and experiences freely by integrating linguistic, pragmatic and sociolinguistic competences (Gutiérrez, Puello, \& Galvis, 2015).

The first theory regarding the combination of visuals and text was that of dual coding theory (DCT). It has been used by many researchers to describe and explain the impact of visuals on cognition and reading comprehension. As Clark and Paivio (1991) stated 'cognition is shaped by two subsystems which are verbal and non-verbal'. The first system has a role in learning the language and the second system has a role in non-linguistic objects and events. These systems work hand in hand in language acquisition. As a result, picture combinations, mental visualization, and verbal illustrations might come as a powerful way to enhance learning through text, varying from school level to university level (Clark \& Paivio, 1991, p. 163).

Another support comes from Krashen's theory of comprehensible input ('Comprehensible Input" that belongs to level 'I +1 '). This hypothesis believes that developing in a language is dependent on the acquisition process, not the learning process. Based on the hypothesis, learners will be able to achieve or make an improvement in their learning when they receive second language input which is one phase above their current phase of linguistic competence. It usually occurs in the process of learning that involves word selection, context, explanation and the use of visuals.

\section{Some Related Findings of Previous Research of Technology \& Motivation}

In one study conducted by Megawati (2016) about students' perspectives on selfefficacy toward EFL writing, it was reported that learning how to write can be both interesting and frustrating due to the environment and motivation of each individual. Moreover, previous literature has shown that the involvement of technology in teaching writing can increase students' motivation in the learning process. (Abdel-Hack \& Helwa, 
2014; Fajaria, 2014; Giacomini, 2015; Hadi, 2017; Hapsari, Seniwegiasari, \& Fauzi, 2016; Harmer, s.d; Herrera Ramírez, 2013; Komara \& Muhamad Ramdani, 2016; Wahyono, 2008).

One study from Lam and Law (2007) entitled The Roles of Instructional Practices and Motivation in Writing Performance investigated which and how the instructional practices are linked to students' motivation and performance in writing. The participants of the study were secondary school students. The participants were asked to complete a written assignment and evaluate the instruction by using a questionnaire to find out their motivation and perception. It was reported that when the teachers applied more motivating strategies, the students' motivation increased. Hence, when they feel motivated, their writing performance was also enhanced. In this study, it also mentioned that students are motivated in literacy when instruction motivates their literacy behavior. However, it is not always true unless teachers are able to identify the instructional strategies that motivate students to write (Lam and Law (2007, p. 146). Vicky Samuel (as cited in Harmer, s.d.) reported that when students were given a chance to post their digital stories on a website, their motivation was increased.

Many studies found that technology is effective tool in enhancing students' motivation to write. Herrera Ramírez (2013) conducted a study on writing skills enhancement when creating narrative texts through the use of collaborative writing and the Storybird Web 2.0 tool. The participants were adult learners. It was found that during the process of collaborative writing, students had a positive attitude towards writing because they were given a chance to select the art galleries to create storyboards, and they regarded it as something new. It was also mentioned that there was a positive relationship between the writing production and students' motivation to write. When the production time increased, students' motivation to write also increased.

Previous studies in Indonesia have shown that technology can increase students' motivation in learning and writing. Wahyono (2008) conducted a study about how to develop an Information Communications Technology (ICT) -based learning model to enhance students' self-management in learning. The result showed that using a learning model with self-management is more effective when compared to the traditional model. It was recommended for the teachers as an alternative way in learning because it can enhance students' cognition, skills, and motivation. Similarly, Komara and Muhamad Ramdani (2016) found that Edmodo is an effective tool to increase students' motivation in helping students to accomplish the affective, cognitive, integrative social relationships, and task achievement. 
For a specific skill like writing, previous studies indicate that the use of technology also plays an important role. Fajaria (2014) conducted an accordion book project for reluctant writers. He used social media to assign students writing tasks. The project was fun, original and beneficial for students. It was reported that with the use of social media, students' motivation is enhanced because they were encouraged to write confidently.

Previous studies on Storybird have shown that it is a great tool to support writing (Abdel-Hack \& Helwa, 2014; Giacomini, 2015; Hapsari et al., 2016). Firstly, it enhances students' motivation, both for writing and reading. Even before starting to write, students are able to read stories made by many authors throughout the world. It is one of the advantages of this website. In the early stage, it provides an attraction for people whose age varies from young learners to adults. Furthermore, students have a chance to work with peers without fear of making mistakes because the tool works so easily. Students may be able to edit and retrieve their work whenever they want. According to Rebecca Webb:

"It is believed that such peer-to-peer interaction not only improves both writers' and reviewers' reading and composing processes, but it also creates more motivation in the students to write well because the writer has a tangible audience to consider and from whom or she will receive instant feedback" (Webb, 2015, p. 175).

When students finally feel the work is ready to be published and seen by other authors in the world, they will get feedback, not only from teachers, but also people who read their stories. Hence, it is very beneficial for collaborative writing.

Storybird has been classified as a potential tool in EFL writing skill for many reasons. It is considered as an authentic material in terms of learning English. It helps students in generating ideas, enhancing critical thinking skills, learning grammar and vocabulary, and helping students to be more autonomous in learning. In fact, teachers are no longer needed as the main resource in learning. Students may need help from teachers but not that much. They will be able to work inside or outside the classroom with the assistance from teachers (Giacomini, 2015).

Another supported finding was highlighted by Sari and Al-Hafizh (2014). The study found that Storybird brings many advantages in teaching recounts. The first advantage is it motivates students to write because of its attractive layout, full of pictures to be selected. The 
second advantage is it helps to promote students' critical thinking by giving comments and feedback. Next, it allows students to repair their writing in a simple way. The evidence finds that Storybird is a useful tool for students to work in a collaborative way in terms of positive teamwork and knowledge expansion.

Giacomini (2015) ) conducted research about the use of Storybird in a young learners' creative writing class. What she found was also important. It is not only motivating for her students to write in English but also in their first language (L1). Students are free to write even though the teacher does not assign them to do so. In this study, the researcher asked the students to write a narrative story. It became motivating for students to write in English because they are free to express their ideas into words in a creative way. Consequently, they can consolidate previous knowledge and practice the new vocabulary and, of course, grammar.

In addition, Fatimah and Santiana (2017) conducted a study about student-teachers' perception on the use of technology in the classroom and reported that it resulted in better motivation, focus, creativity, and confident in learning. Therefore, teachers are expected to equip themselves with the ability to use technology for teaching as a preparation to face $21^{\text {st }}$ century education.

\section{FINDINGS AND DISCUSSION}

Previous studies in Indonesia have shown that narrative writing has attracted great attention. Most prior studies focused on improving students' narrative writing skills in the secondary level (either low or high secondary level) using a specific technique which mainly involved pictures and visuals (Ali \& Hasanah, 2014; Asrifan, 2015; Megawati \& Anugerahwati, 2012). The teachers often conduct the writing instruction through the traditional classroom setting, including teaching sentence by sentence, lectures, and formfocus on structure and grammar. However, most of the previous studies do not take into account the use of technology, such as digital story writing. Digital story writing is one of the alternatives that provide solutions for students to learn narrative writing skills. It was reported that since the availability of technology such as social media (Facebook, Edmodo \& blog), narrative learning multimedia (NLM) has helped Indonesian teachers to enhance student's writing skills and interest. The students feel that through the use of technology, writing seems 
to be less difficult and time consuming, and more motivating (Cahyono \& Mutiaraningrum, 2015; Fajaria, 2014).

\section{CONCLUSION}

From the previous findings, Indonesian students have a problem with writing in both general and specific cases. Commonly, the teaching approach seems to be one of the crucial factors that distract students' attention in writing, along with a lack of motivation, weak teaching strategies, and lack of media. Specifically, students face several problems in the language and writing components, which are composition, vocabulary, grammar, and mechanic.

In summary, the teacher should use an appropriate approach in writing, teach students the strategy in writing, and use media to attract students' attention, and thus increase students' motivation. Hence, they will be motivated to learn how to write accordingly. Additionally, there is a variety of media which teachers could utilize that can enhance students' writing, especially related to writing components,

Finally, teachers should guide the students to make a plan about how to begin prewriting, drafting, and revising steps in writing, as well as provide attractive techniques. Writing can be taught in many ways, including within the learner's community and by becoming a facilitator in giving feedback. Since writing has to follow many stages and is a long process, the possibility of making mistakes is high, so it is important to let students recognize their errors and self-correct them.

\section{BIBLIOGRAPHY}

Abdel-Hack, E. M., \& Helwa, H. S. A.-H. A. (2014). Using digital storytelling and weblogs instruction to enhance EFL narrative writing and critical thinking skills among EFL majors at faculty of education. Narrative, 2004(2002).

Abuzahra, N., Farrah, M. A.-H., \& Zalloum, S. (2016). Using cartoon in language classroom from a constructivist point of view.

Ali, A., \& Hasanah, U. (2014). Using series pictures to develop the students' ideas in English narrative writing.

Ariyanti, A. (2016). The teaching of EFL writing in Indonesia. Dinamika Ilmu: Jurnal Pendidikan, 16(2), 263-277. 
Asrifan, A. (2015). The use of pictures story in improving students' ability to write narrative composition. International Journal of Language and Linguistics, 3(4), 244. doi:10.11648/j.ijl1.20150304.18

Brown. (2007). Teaching by principles: an interactive approach to language pedagogy (3th): Longman.

Brown, \& Lee, H. (2015). Teaching by principles (Fourth ed.): Pearson Education, Inc.

Cahyono, B. Y., \& Mutiaraningrum, I. (2015). Indonesian EFL teachers' familiarity with and opinion on the internet-based teaching of writing. English Language Teaching, 9(1), 199.

Canale, M., \& Swain, M. (1980). Theoretical bases of communicative approaches to second language teaching and testing. Applied linguistics, $1,1$.

Clark, J. M., \& Paivio, A. (1991). Dual coding theory and education. Educational psychology review, 3(3), 149-210.

Peraturan menteri pendidikan dan kebudayaan tentang standar isi pendidikan dasar dan menengah, (2016).

Fajaria, N. H. (2014). An accordian book project for reluctant writers. The 61st TEFLIN Proceeding., 4.

Fatimah, A. S., \& Santiana, S. (2017). Teaching in 21st century: Studentsteachers'perceptions of technology use in the classroom. Script Journal: Journal of Linguistic and English Teaching, 2(2), 125-135.

Ferdhiyanto, F. Y. (2014). Junior high school students' grammar problems in their written production. Program Studi Pendidikan Bahasa Inggris FBS-UKSW.

Fortunasari. (2016). The use of of information and communication technologies (ICTs) in English as foreign language learning: A review of recent practices in Indonesia. [-]. ASIAN EFL JOURNAL, 92(92), 21. doi:-

Giacomini, L. (2015). Teaching techniques: using" Storybird" in young Learners' creative writing class. Paper presented at the English Teaching Forum.

Gibbons, P. (2002). Scaffolding language, scaffolding learning: teaching second language learners in the mainstream classroom: Heinemann Portsmouth, NH.

Gutiérrez, K. G. C., Puello, M. N., \& Galvis, L. A. P. (2015). Using pictures series technique to enhance narrative writing among ninth grade students at Institución Educativa Simón Araujo. English Language Teaching, 8(5), 45. 
Hadi, T. N. (2017). Teaching writing through digital story telling: the practical use of Storybird.

Hapsari, C. T., Seniwegiasari, F., \& Fauzi, N. A. (2016). The effectiveness of Storybird platform for improving students' writing skill in recount. Paper presented at the Proceeding of the International Conference on Teacher Training and Education.

Harmer, J. (s.d). The practice of English language teaching (Fifth ed.): Pearson Education.

Herrera Ramírez, Y. E. (2013). Writing skill enhancement when creating narrative texts through the use of collaborative writing and the Storybird Web 2.0 tool. Colombian Applied Linguistics Journal, 15(2), 166-183.

Horner, B., Nordquist, B., \& Ryan, S. M. (2017). Economies of writing: revolutions in rhetoric and composition: University Press of Colorado.

Hull, G. A., \& Nelson, M. E. (2005). Locating the semiotic power of multimodality. Written communication, 22(2), 224-261.

Hyland, K. (2003). Second language writing: Cambridge University Press.

Johnson-Sheehan, R. (2005). Technical communication today: Pearson/Longman.

Kent, D. B. (2015). Avenues for use of multimedia in language teaching: crafting digital stories in the EFL context. Paper presented at the The 19th STEM International Conference: How to Develop Movie and Media Materials.

Knapp, P., \& Watkins, M. (1994). Context, text, grammar. Broadway: Text Productions.

Komara, U., \& Muhamad Ramdani, J. (2016). Motivating students through EDMODO (a blended learning in grammar class).

Kumpawan, P. (2014). The effects of Fisher and Frey's gradual release of responsibility model on writing ability of tenth grade students (Master), Chulalongkorn University, Thailand.

Lam, S.-F., \& Law, Y.-K. (2007). The roles of instructional practices and motivation in writing performance. The journal of experimental education, 75(2), 145-164.

Lipson, M. Y., \& Wixson, K. K. (2003). Assessment and instruction of reading and writing difficulty: An interactive approach: Allyn \& Bacon.

Lorenz, B., Green, T., \& Brown, A. (2009). Using multimedia graphic organizer software in the prewriting activities of primary school students: What are the benefits? Computers in the Schools, 26(2), 115-129. 
Martin, S. (2012). Does instructional format really matter? Cognitive load theory, multimedia and teaching English Literature. Educational Research and Evaluation, 18(2), 125152. doi:10.1080/13803611.2012.659899

Matsuda, P. K. (2003). Basic writing and second language writers: Toward an inclusive definition. Journal of Basic Writing, 67-89.

McAdams, L. (2013). Innovate literacy instruction with a classroom computer: A solid rationale for the integration of specific digital tools. Texas Journal of Literacy Education, 1(1), 54-59.

Megaiab, M. M. (2014). The English writing competence of the students of Indonesian senior high school. Paper presented at the Proceedings of the West East Institute (WEI) Academic Conference, Indonesia.

Megawati, F. (2016). Tertiary level exchange students' perspectives on self-efficacy: Toward EFL writing.

Megawati, F., \& Anugerahwati, M. (2012). Comic strips: a study on the teaching of writing narrative texts to Indonesian EFL students. Teflin Journal, 23(2), 183.

Musa, A. S. (2016). Technology and language: a review of students' perceptions of blog in some selected English as a second language writing classes. Malaysian Journal of Distance Education, 18(1), 1-12.

Mustafa, F., Kirana, M., \& Bahri Ys, S. (2016). Errors in EFL writing by junior high students in Indonesia. International Journal of Research Studies in Language Learning, 6(1).

Mustafa, F., \& Samad, N. M. A. (2015). Cooperative integrated reading and composition technique for improving content and organization in writing. Studies in English Language and Education, 2(1), 30-45.

Pan. (2008). A Genre based approach for teaching writing to low proficiency EFL college students. PASAA: Journal of Language Teaching and Learning in Thailand, 42, 7994.

Pifarré Turmo, M., \& Fisher, R. (2011). Breaking up the writing process: how wikis can support understanding the composition and revision strategies of young writers. Language and Education, 2011, vol. 25, núm. 5, p. 451-466.

Priyana, J. (2014). English curriculum 2013: goals, contents, methods, and assessment techniques. Paper presented at the 11 th JETA International Conference 18-19 June.

Ramirez, G. (2016). Usage of multimedia visual aids in the English language classroom: a case study at Margarita Salas secondary school (Majadahonda). Master's Thesis. 
Universitas Complvtensis Matritensis.(Online). Retrieved from https://www. ucm. es/data/cont/docs/119-2015-03-17-11. MariaRamirezGarcia2013. pdf on December 27 th.

Robin, B. (2006). The educational uses of digital storytelling. Paper presented at the Society for Information Technology \& Teacher Education International Conference 2006, Orlando, Florida, USA. https://www.learntechlib.org/p/22129

Sakkir, G., Rahman, Q., \& Salija, K. (2016). Students' Perception on Social Media in Writing Class at STKIP Muhammadiyah Rappang, Indonesia. International Journal of English Linguistics, 6(3), 170.

Sari, G. M., \& Al-Hafizh, M. (2014). Teaching writing a recount text at junior high school by using Storybird media. Journal of English Language Teaching, 3(1), 212-219.

Silva, T. (1993). Toward an understanding of the distinct nature of L2 writing: The ESL research and its implications. TESOL quarterly, 27(4), 657-677.

Smith, C. (2011). Narrative writing in native English and ESL learners: Developmental Trajectories and predictors.

Sukandi, S. S. (2015). The "voice" in composition: reviewing the essence of writing culturally in English for Minangkabau-Indonesian EFL students. Proceedings of ISELT FBS Universitas Negeri Padang, 3, 480-486.

Wahyono, U. (2008). Pengembangan model pembelajaran TIK untuk meningkatkan pengaturan diri dalam belajar siswa.

Wang, A. Y. (2012). Exploring the relationship of creative thinking to reading and writing. Thinking Skills and Creativity, 7(1), 38-47. doi:10.1016/j.tsc.2011.09.001

Webb, R. K. (2015). Teaching English writing for a global context: An examination of NS, ESL and EFL learning strategies that work. PASAA: Journal of Language Teaching and Learning in Thailand, 49, 171-198.

Wen, X. (2017). The effect of rule-based scaffoldings on second grade students' digital storytelling.

Widiati, U., \& Cahyono, B. Y. (2006). The teaching of EFL writing in the Indonesian context: The state of the art. Jurnal Ilmu Pendidikan, 13(3). 
Yunus, M. M., Salehi, H., Tarmizi, A., Syed, S., \& Balaraman, S. (2011). Using digital comics in teaching ESL writing. Wseas. us, 53-58.

Zakaria, S. M., Yunus, M. M., Nazri, N. M., \& Shah, P. M. (2016). Students' experience of using Storybird in writing ESL narrative text. Creative Education, 7(15), 2107. 